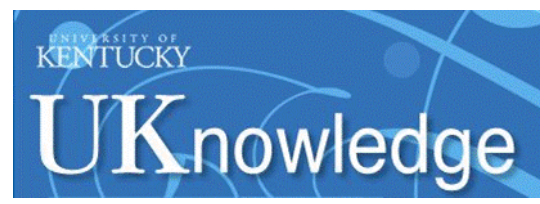

University of Kentucky

UKnowledge

$11-1-2014$

\title{
Use of Social Media in Dental Schools: Pluses, Perils, and Pitfalls from a Legal Perspective
}

Joseph W. Parkinson

University of Kentucky

Sharon P. Turner

University of Kentucky, sharon.turner@uky.edu

Follow this and additional works at: https://uknowledge.uky.edu/ohp_facpub

Part of the Dentistry Commons

Right click to open a feedback form in a new tab to let us know how this document benefits you.

\section{Repository Citation}

Parkinson, Joseph W. and Turner, Sharon P., "Use of Social Media in Dental Schools: Pluses, Perils, and Pitfalls from a Legal Perspective" (2014). Oral Health Practice Faculty Publications. 1.

https://uknowledge.uky.edu/ohp_facpub/1

This Article is brought to you for free and open access by the Oral Health Practice at UKnowledge. It has been accepted for inclusion in Oral Health Practice Faculty Publications by an authorized administrator of UKnowledge. For more information, please contact UKnowledge@lsv.uky.edu. 
Use of Social Media in Dental Schools: Pluses, Perils, and Pitfalls from a Legal Perspective

\section{Notes/Citation Information}

Published in Journal of Dental Education, v. 78, no. 11, p. 1558-1567.

Reprinted by permission of Journal of Dental Education, Volume 78, no. 11 (Nov. 2014). Copyright 2014 by the American Dental Education Association. http://www.jdentaled.org 


\title{
Use of Social Media in Dental Schools: Pluses, Perils, and Pitfalls from a Legal Perspective
}

\begin{abstract}
Joseph W. Parkinson, D.D.S., F.A.G.D.; Sharon P. Turner, D.D.S., J.D.
Abstract: One of the ways dental education is changing the way it is preparing the next generation of learners is through efficient utilization of interactive social media. Social media, which facilitates interaction and sharing of new ideas, is being utilized to educate students, residents, and faculty. Unfortunately, as with most improvements in technology, there are growing pains. Faculty, student, and patient interaction on social media platforms, such as Facebook and Twitter, can lead to inappropriate or embarrassing situations. Striking the appropriate balance between free speech rights of students and faculty and the need for colleges and universities to have efficient operations is often left to the judicial system. The concepts of free speech and contract law and how each is applied in educational settings should be understood by students, faculty, and administrators. This article provides a review of legal cases that led to current social media policies, as well as present-day cases that exemplify the application of these principles, to help dental educators gain a greater understanding of the boundaries of protected speech. It also provides a set of sample guidelines for communicating through these media.
\end{abstract}

Dr. Parkinson is Assistant Dean for Predoctoral Clinical Operations and Assistant Professor, Department of Oral Health Practice, University of Kentucky College of Dentistry; and Dr. Turner is Dean and Professor, Department of Oral Health Practice, University of Kentucky. Direct correspondence and requests for reprints to Dr. Joseph W. Parkinson, Department of Oral Health Practice, University of Kentucky College of Dentistry, 800 Rose Street, Lexington, KY 40536-0297; 859-323-6552; joseph.parkinson@uky.edu.

Keywords: dental education, social media, educational technology, free speech, contract law

Submitted for publication 1/20/14; accepted 4/9/14

$\mathrm{E}$ ducation is facing changes driven by financial pressures, innovation, technological enhancements, and changing social norms. Educators, especially those in the higher education area, are rapidly seeing their roles change from "sage on the stage" to facilitators of students' acquisition of information on their own or provokers of critical analysis and application of theory to real or simulated experience. Conversely, students' roles are changing from passively sitting in classrooms where they are spoonfed fact and theory to being responsible for finding the necessary knowledge in an active way and demonstrating their ability to analyze the validity and strength of the information source. This change in educational methodology and expectation matches well with the Millennial generation, which is known for its philosophy of action, much like the old Nike ad instructs, "Just Do It." In fact, these students themselves have helped drive the changes in educational methodology and outcomes that are driven by advances in technology and changing expectations in a digital world. Dental students can, and do, access YouTube the night before they are scheduled to perform a restorative or endodontic procedure for a patient and watch the same procedure being performed by a practicing clinician. Ironically, faculty members who may be less technologically savvy can also make use of YouTube technology and learn how to enter treatment plans into the school's electronic health record by viewing a demonstration by a student at another institution that has the same system.

Dental educators are beginning to utilize various forms of social media to educate students more effectively and adjust pedagogical methodology with the new generation of students in mind. In contrast to Web 1.0, which was the initial launch of the Internet, social media depend on the collaboration of many content creators and include sites such as Facebook, Twitter, and YouTube and interactive forms such as blogs and Wikis. The exchange of information among larger groups of people made possible by these entities encourages increased participation and interaction (Figure 1). These technologies encourage a social component and user-generated content in the form of text, video, and photo postings. In this way, social media can be used to promote learning based on communication and the sharing of content. ${ }^{1}$ Schools and universities are now utilizing Facebook and Twitter sites to post manuals and study guides 


\section{The Evolution of Social Media}

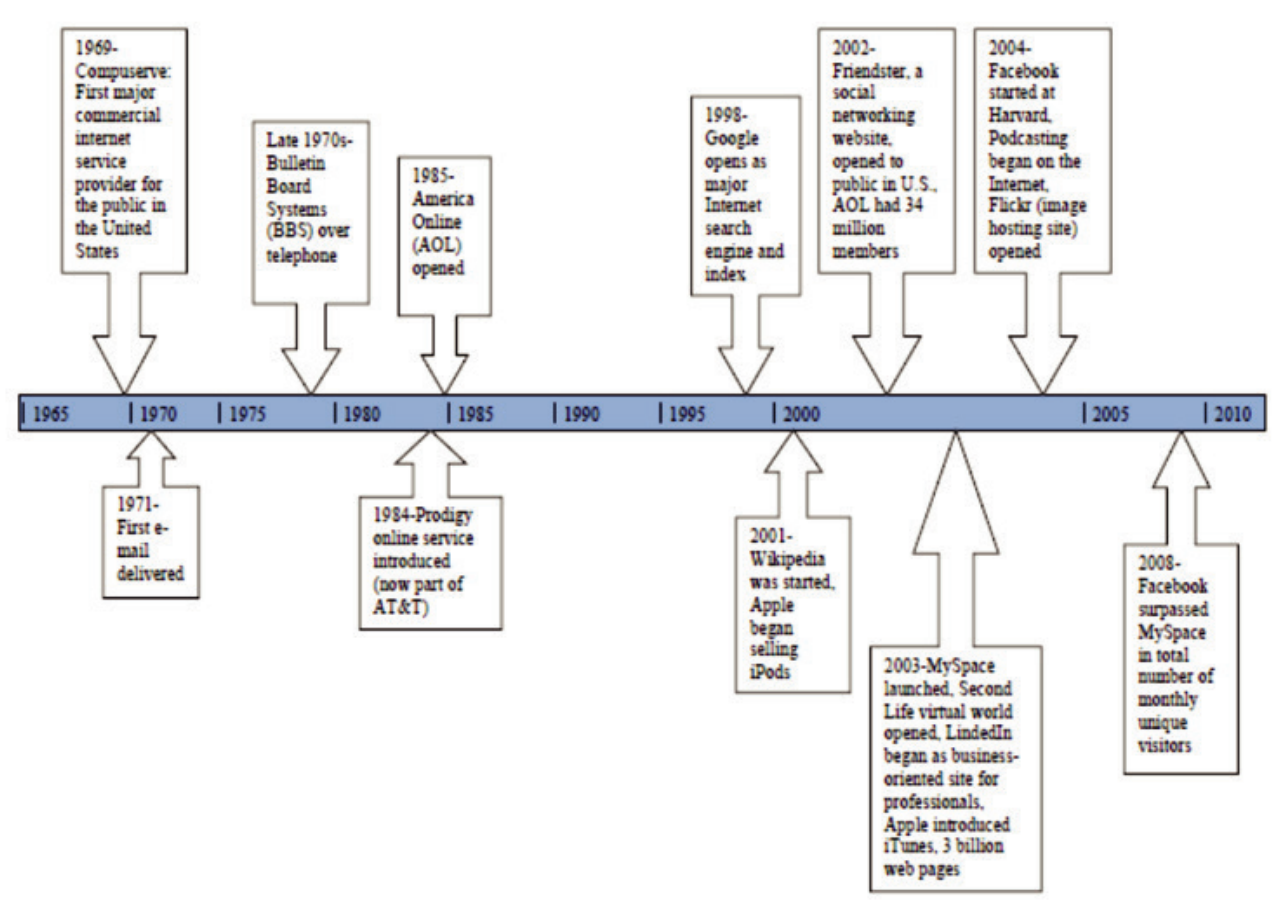

Figure 1. The evolution of social media

as well as blogs to discuss clinical cases and patient outcomes in an effort to enhance relevance in delivery methodology among students. The ubiquitous nature of digital access allows faculty members and students to network with colleagues at other schools and receive guidance or critical information instantaneously.

However, along with the positive impacts that new technology and communication sites can bring, there are also some issues, problems, and questions that arise. Often with social media sites, the previously clearer delineation between professional and personal communications and applications gets blurred. People have a tendency to "say" and post written comments on websites that they would have never communicated in face-to-face dialogue, especially with one who is not a close professional associate or family member. These media seem to remove filters to conversational constraints (whether the filters are conscious or subconscious) that developed over years as acceptable social convention and good manners. Communication, which can be engaged rapidly with little advanced thought, may have significant repercussions ranging from legal liability for violation of laws or general violation of privacy, violation of institutional policy, or damage to one's own or another's professional reputation.

Both students and faculty members utilize social media for personal and professional purposes. Both groups also need guidance in how to utilize these communication tools to prevent crossing a line that could lead to embarrassment, discipline, or other negative consequences. An understanding of significant legal cases and trends in evolving social media law will help users of all forms of electronic communication utilize new technology with more confidence and success.

Faculty members employed at public colleges and universities should have an understanding of their free speech rights, as well as what is legally protected or unprotected speech. Faculty members, students, and administrators at both public and private institutions should understand how contract law is applied in educational settings to prevent misunderstandings 
and unwanted litigation. Direct faculty communications with patients and students on social media are areas where a potential loss of accepted boundaries between personal and professional interactions may occur. Faculty posting of personal information that may be unflattering to both the individual and the institution is another large area for potential concern. Three important U.S. Supreme Court cases are critical in the evaluation of free speech rights of public school faculty members. Taken together, these cases create a three-part analysis for making decisions as to whether any given speech is constitutionally protected. These cases do not specifically address cyberspeech rights, but are applied by analogy just as any evolving body of law is built. Private school faculty members' rights are not evaluated by these cases because employees in private schools are not protected to the same degree by the First and Fourteenth Amendments since their employers are not agents of a government. These amendments refer to citizens' rights that are not to be infringed upon by the government. Private schools may use employment contracts with faculty to restrict speech or activities to be consistent with the mission and nature of the institution.

In the realm of student free speech, there are no U.S. Supreme Court cases that have dealt directly with the web-based free speech rights of students at public universities. The lack of legal guidance has created confusion in dealing with student free speech rights, as there is no basic doctrine to determine what constitutes protected speech and what does not. Courts have decided cases in this emerging area of the law on an individual basis. In some cases, the outcome has hinged on whether or not a contract or waiver was signed by the student at both public and private schools. These cases can be further subdivided into threatening or hate speech cases and patient confidentiality cases. Some of these cases have dealt directly with the provision of health care or instruction in health care and thus would be applicable to health care education.

By reviewing past and present-day cases and developing a clear understanding of Supreme Court and lower court rulings on whether or not speech is protected, students, faculty members, and administrators can gain a new understanding of existing social media boundaries between protected and unprotected free speech, as well as a better understanding of the importance of contract law. In addition to reviewing these cases and the principles they have raised, this article presents guidelines for safeguards, modeled on those of the American College of Physicians and Federation of State Medical Boards, to help faculty and students make informed decisions about what is acceptable or not to post on the Web or send to individuals. Flexibility and adaptability will always be necessary because technology and digital communications are changing and expanding at a rapid pace. With increased knowledge and understanding, students, faculty members, and administrators will be able to efficiently utilize this new and powerful technology to improve education and patient care.

\section{Student Civil Rights and Hate Speech Cases}

A Supreme Court case in 1942 and two federal district court cases from the 1990s have helped to shape university social media policies by focusing their intent on unprotected speech. In 1942, the Supreme Court decided the case of Chaplinsky v. New Hampshire. ${ }^{2}$ In this case, the Court recognized only two levels of speech: speech that the First Amendment protects absolutely, and speech that it does not protect at all. The only category of speech not protected included "fighting words," which "by their very utterance inflict injury or tend to incite an immediate breach of peace." This case formed the background for two cases in the 1990s related to higher education and free speech that involved student violations of Hate Speech Codes at the University of Michigan and the University of Wisconsin. These cases pitted the civil rights of minority students against the free speech rights of other students, and in both cases, free speech rights prevailed. The cases were Doev. University of Michigan ${ }^{3}$ and UWM Post v. Board of Regents of the University of Wisconsin System. ${ }^{4}$

After an increasing number of racial incidents at the University of Michigan, a policy was issued attempting to regulate discriminatory harassment of minority students. Through this policy, individuals were subject to discipline for behavior that stigmatized individuals based on being part of a particular group or threatened an individual's employment or academic advancement for the same reason. In its decision, the district court found that the policy was both overbroad and vague, both of which are standard legal reasons for invalidating laws, or in this case policies, on Constitutional grounds. The court 
reviewed three instances in which it found that the policy was applied to protected speech, concluding "It is clear that the policy was overbroad both on its face and as applied." In UWM Post v. Board of Regents of the University of Wisconsin System, the district court similarly found the university's policy to be overbroad and vague. The court felt that the policy went beyond the fighting words doctrine and interfered with the constitutional right to freedom of speech.

These cases illustrate the need for clear and concise policies in the university setting delineating what is and is not acceptable speech. Policies that are overreaching and vague and infringe upon protected speech are unlikely to be upheld by the courts. These cases represented victories for free speech and required universities and all public organizations to reevaluate their policies as to what constitutes acceptable verbal and written communications. Consequently, these cases clearly have relevance in evaluation and construction of social media policies.

Table 1 summarizes other U.S. Supreme Court Cases related to student free speech rights. The cases presented in this table all dealt with students in public secondary schools, and all students involved were minors at the time of the incidents that led to the litigation. While instructive, the outcomes are in at least some part related to the ages of the students involved. These cases established what rights public employees have regarding freedom of speech. For this reason, although these cases are instructive, analogies to the hate speech codes are most relevant to university-level students.

\section{Patient Confidentiality Cases}

There are two recent lower court cases involving nursing education programs that serve to clarify understanding of the intersection of social media and patient confidentiality. ${ }^{5}$ These cases highlighted the need for schools to establish well-thought-out social media policies that are grounded in First Amendment law and create a definite distinction between academic and disciplinary dismissal of students who breach policy or law.

In the case of Byrnes v. Johnson County Community College, ${ }^{6}$ Doyle Byrnes and three other nursing students were dismissed from the Nursing School at Johnson County Community College (JCCC) for posting photos on Facebook of a placenta they were examining in an obstetrics and gynecology clinical course. The students had obtained permission from a faculty member to take the picture, on the condition that no identifying marks were present in the photograph. All four students were dismissed from the JCCC on November 11, 2010, because the school viewed the posting of the photographs as "unprofessional" and a disruption to the learning environment.

In dental schools, students are given clear guidelines that photographs taken during the course of treatment maintain patient confidentiality, unless permission is given by the patient for his or her face to be shown. However, these guidelines to dental students are based on federal law in addition to aca-

Table 1. Key cases regarding student free speech

\begin{tabular}{|c|c|c|c|c|c|}
\hline Case & $\begin{array}{l}\text { Cyberspeech } \\
\text { Importance }\end{array}$ & Main Issue & $\begin{array}{l}\text { Principles } \\
\text { Established }\end{array}$ & $\begin{array}{l}\text { Effect on Dental } \\
\text { School }\end{array}$ & $\begin{array}{l}\text { Student Free } \\
\text { Speech }\end{array}$ \\
\hline $\begin{array}{l}\text { Tinker et al. v. Des } \\
\text { Moines Independent } \\
\text { School District et al. }\end{array}$ & $\begin{array}{l}\text { Student free } \\
\text { speech }\end{array}$ & $\begin{array}{l}\text { Freedom of speech } \\
\text { doesn't stop at the } \\
\text { schoolhouse gate }\end{array}$ & $\begin{array}{l}\text { Establish student } \\
\text { free speech }\end{array}$ & $\begin{array}{l}\text { Gives students some } \\
\text { freedom of speech }\end{array}$ & Increased \\
\hline $\begin{array}{l}\text { Bethel School District } \\
\text { No. } 403 \text { v. Fraser }\end{array}$ & $\begin{array}{l}\text { Lewd, vulgar } \\
\text { not acceptable }\end{array}$ & $\begin{array}{l}\text { Lewd, offensive } \\
\text { speech }\end{array}$ & $\begin{array}{l}\text { Students not same } \\
\text { as adults; Tinker } \\
\text { rule not absolute }\end{array}$ & $\begin{array}{l}\text { Schools can limit or } \\
\text { discipline if lewd or } \\
\text { vulgar }\end{array}$ & Decreased \\
\hline $\begin{array}{l}\text { Hazelwood School } \\
\text { District v. Kuhlmeier }\end{array}$ & $\begin{array}{l}\text { Schools impri- } \\
\text { matur; limitation } \\
\text { when pedagogi- } \\
\text { cal issue }\end{array}$ & $\begin{array}{l}\text { Censor for reason- } \\
\text { able educational } \\
\text { purpose }\end{array}$ & Clearest decision & $\begin{array}{l}\text { Cannot use school } \\
\text { logo; disclaimer not } \\
\text { representing school }\end{array}$ & Decreased \\
\hline $\begin{array}{l}\text { Morse et al. v. Fred- } \\
\text { erick }\end{array}$ & $\begin{array}{l}\text { Beyond school- } \\
\text { house gate }\end{array}$ & Drug promotion & $\begin{array}{l}\text { First Amendment } \\
\text { does not require } \\
\text { drug promotion }\end{array}$ & $\begin{array}{l}\text { Expanded past } \\
\text { schoolhouse gate, so } \\
\text { schools could limit } \\
\text { off-campus Internet } \\
\text { cyberspeech }\end{array}$ & Decreased \\
\hline
\end{tabular}


demic or behavioral policies governing professionals. In the Byrnes case, the plaintiff contended the students were given permission to take the pictures by the faculty member and thus disciplining them for the posting later was inappropriate. She also contended that her due process rights were violated by not providing her with the proper disciplinary appeals process and by failing to afford her with an impartial arbiter to preside over her petition for review. The JCCC correctly noted that higher education institutions are given broad discretion by the courts with respect to their academic decisions, and it asserted that this was an academic violation based on professionalism standards rather than a conduct violation.

However, in its holding, the District Court of Kansas first ruled that the action taken by the institution was not deemed to be due to an "academic" infraction, but rather one that was "disciplinary." Because it was not an "academic" infraction, the school was not afforded the discretion it sought regarding discipline of the plaintiff. Second, the court noted that neither the JCCC's Nursing Code of Conduct nor any other code of conduct relating to the JCCC and/or its nursing school regulated student photography of classroom or clinical events. The Code of Conduct also did not prohibit transmittal of photographs to others, including transmittal on social media like Facebook. The supposed "violation" was one of a sense of propriety, not of a code of conduct, so the court found that the appeal process did in fact deny the students their due process rights. Note that this case may have had a different outcome if a picture of a patient in a clinical environment had been posted without the patient's permission because of breach of federal law, which should supersede institutional policy or form the grounds for conduct related to an offense via the finding of liability.

In another professional school case involving a laboratory situation, a University of Louisville nursing student was dismissed from the university because of posts she made on her page blog on MySpace (a social networking site with an emphasis on music). ${ }^{7}$ After observing a live birth as part of her obstetrics class, she wrote a blog about the birth in a manner that was deemed by the University of Louisville to be unprofessional. The school dismissed the plaintiff based on breach of patient confidentiality and violation of the nursing school's Honor Code. In her defense, the plaintiff alleged violation of her First and Fourteenth Amendment rights and argued that provisions of the Honor
Code and the confidentiality agreement were unconstitutionally "overbroad and vague," the same words used in the decision in the Michigan hate speech case. She also indicated her belief that the agreement she signed, the patient confidentiality agreement, and the Honor Code did not provide enough guidance for her to understand what she could or could not post on social media.

In 2009, the District Court of Western Kentucky granted a motion for summary judgment and reinstatement of the nursing student at the University of Louisville, basing its decision on breach of contract. The court stated that the post did not contain any identifying information pertaining to the birth mother and thus did not violate the confidentiality provision of the Honor Code. Also, the blog did not violate the professionalism provision of the Honor Code because it was not created or used in any professional context and was not representative of the school. According to the district court, because the plaintiff and the University of Louisville entered into a contract regarding the Honor Code and the confidentiality agreement and the plaintiff did not violate that contract, the university breached it when she was dismissed. In 2011, the Sixth Circuit Court vacated the order, indicating that summary judgment was improperly granted because the plaintiff had not raised the argument of breach of contract in her complaint and therefore the court could not award reinstatement to her based on this ground. The court declined to rule on Constitutional grounds, and the case was remanded to a lower court.

In 2012, the district court found in favor of the university and dismissed the plaintiff's case. Regarding the First Amendment claim, the court said the plaintiff and the birth mother agreed that they would only communicate with the professor about the pregnancy and birth. The court said that because the plaintiff agreed not to publicly disseminate the information about the birth, she was not entitled to claim that she had a Constitutional right to do so. Regarding the Fourteenth Amendment due process claim, the court decided that the plaintiff's dismissal was an academic rather than a disciplinary one. The rationale for this position was held to be that, in a professional program, a student's compliance with accepted standards of the profession are important factors in assessing the student from an academic perspective. Therefore, the school was granted summary judgment on the procedural grounds. The Court of Appeals subsequently affirmed the dismissal of the plaintiff's case. 
From these cases, it is evident that a clear policy on social media that includes clarification that breaking the rules will result in academic discipline, as well as developing and adhering to a fair and unbiased due process, are pivotal requirements for universities to be able to regulate and discipline social media transgressions. The JCCC did not have a clear social media policy, one that included rules about photography and transmittal of clinical or patient information on social media. It also apparently did not have ethical evaluations within its student competency evaluations. Had there been such a competency evaluation, the plaintiff's actions might well have been characterized as an academic violation. The court in the Yoder v. University of Louisville case specifically mentioned the Supreme Court case of Board of Curators of the University of Missouri v. Charlotte Horowitz ${ }^{8}$ in making the point that the courts generally give schools wide latitude regarding academic dismissals, whereas dismissals that are made for conduct or behavioral reasons are much more rigorously scrutinized.

It is particularly important in health care education to evaluate the ethics and character of the prospective graduates because they will be providing care to the public upon graduation. The public relies on its institutions to graduate competent, ethical practitioners; therefore, behavior that indicates a deficit in character and ethics would certainly fall within the parameters of an academic infraction rather than a conduct infraction. It would seem prudent that competency evaluations for health professions students should always include an evaluation of the student's ethics, professionalism, and sound judgment as a way to evaluate if institutions are graduating ethical practitioners.

\section{Faculty as Public Employee Cases}

Inappropriate behavior and judgment by faculty members viewed on social media and improper communication with students or patients on the Web are two areas that have led to discipline and/or employment termination. Faculty members at public universities are considered government employees, so their activities on social media will be evaluated using guidelines that are associated with the rights of such employees. Faculty members at public universities who intentionally communicate directly with students or patients via social media or who have posts deemed to be inappropriate that are not in direct communication with students or patients will more than likely be evaluated using a rubric elucidated by three Supreme Court cases. ${ }^{9}$ These three cases,

Table 2. Key cases regarding public employee free speech

\begin{tabular}{|c|c|c|c|c|c|}
\hline Case & $\begin{array}{l}\text { Cyberspeech } \\
\text { Importance }\end{array}$ & Main Issue & $\begin{array}{l}\text { Principles } \\
\text { Established }\end{array}$ & $\begin{array}{l}\text { Effect on Dental } \\
\text { School }\end{array}$ & $\begin{array}{l}\text { Public Employee } \\
\text { Free Speech }\end{array}$ \\
\hline $\begin{array}{l}\text { Pickering v. Board of } \\
\text { Education }\end{array}$ & $\begin{array}{l}\text { Boundaries for } \\
\text { limitations on } \\
\text { public employee } \\
\text { free speech }\end{array}$ & $\begin{array}{l}\text { Freedom of speech } \\
\text { for government } \\
\text { employees }\end{array}$ & $\begin{array}{l}\text { Pickering Balanc- } \\
\text { ing Test }\end{array}$ & $\begin{array}{l}\text { Does it affect opera- } \\
\text { tions, patient care, } \\
\text { or confidentiality? }\end{array}$ & Increased \\
\hline Connick v. Myers & $\begin{array}{l}\text { If it doesn't vio- } \\
\text { late fixed tenure } \\
\text { or applicable stat- } \\
\text { ute, not subject to } \\
\text { judicial review }\end{array}$ & $\begin{array}{l}\text { Disruption to } \\
\text { government } \\
\text { office greater } \\
\text { than Myers's need } \\
\text { to distribute } \\
\text { questionnaire }\end{array}$ & $\begin{array}{l}\text { If speech a matter } \\
\text { of public concern, } \\
\text { determine by } \\
\text { content, form, } \\
\text { and context of } \\
\text { statement }\end{array}$ & $\begin{array}{l}\text { Schools can limit } \\
\text { cyberspeech if it } \\
\text { will interfere with } \\
\text { efficient operations } \\
\text { of school or have } \\
\text { deleterious effect on } \\
\text { patient care }\end{array}$ & Decreased \\
\hline $\begin{array}{l}\text { Garcetti et al. v. } \\
\text { Ceballos }\end{array}$ & $\begin{array}{l}\text { Bright-line dis- } \\
\text { tinction on use of } \\
\text { Pickering Balanc- } \\
\text { ing Test }\end{array}$ & $\begin{array}{l}\text { Ceballos's freedom } \\
\text { of speech when } \\
\text { performing core } \\
\text { element of public } \\
\text { service job }\end{array}$ & $\begin{array}{l}\text { When public } \\
\text { employee speaking } \\
\text { as a citizen, the } \\
\text { Pickering Balanc- } \\
\text { ing Test applies; } \\
\text { but when doing } \\
\text { core element of } \\
\text { job, more latitude } \\
\text { given to govern- } \\
\text { ment employers } \\
\text { in disciplining } \\
\text { employees }\end{array}$ & $\begin{array}{l}\text { Negative effect on } \\
\text { whistleblower laws }\end{array}$ & Decreased \\
\hline
\end{tabular}


which provide guidance for public employee free speech issues, are Pickering v. Board of Education of Township High School District 205, ${ }^{10}$ Connick v. Myers, ${ }^{11}$ and Garcetti et al. v. Ceballos (Table 2). ${ }^{12}$

In Pickering, the Supreme Court held that, based on the First Amendment, it was not permissible for a high school teacher to be dismissed from employment for criticizing the Board of Education's preferential funding of athletic activities over academic activities. This holding led to the "Pickering Balancing Test," a two-part test that guides interpretations of limitations on First Amendment rights for public employee speech. The first part of the test involves a determination of whether the employee was acting as a private citizen on a matter of public concern. If acting as a private citizen, the possibility of a free speech issue arises. If not, the employee has no First Amendment cause of action if the employer disciplines him or her in reaction to the speech criticizing employer policy. The second part of the test balances the speaker's interest in making the statement against the employer's interest in maintaining the efficiency of the office. If the interest of the employer outweighs the interest of the speaker, the employee can be disciplined for his or her speech.

In Connick v. Myers, the Supreme Court determined that if a public employee's speech does not touch on a matter of public concern, then there is no First Amendment protection. In this case, an assistant district attorney was told that she was being terminated from her employment because she refused to accept a transfer. She had been told previously that she would be transferred, and she had distributed a questionnaire soliciting the views of her fellow staff members about office morale, confidence in the supervisors, and whether they felt pressured to work in political campaigns. The plaintiff's termination occurred directly after her supervisor, the district attorney for Orleans Parish, learned of the questionnaire. The supervisor told the plaintiff he believed her distribution of the questionnaire to be an act of insubordination. On appeal, the Supreme Court ruled that the questionnaire was not a matter of public concern; therefore, "government officials should enjoy wide latitude in managing their offices, without intrusive oversight by the judiciary in the name of the First Amendment." They believed the survey touched on a matter of public concern in only a very small way and more significantly involved an employee who was upset about internal office policy.
In Garcetti et al. v. Ceballos, the Supreme Court held that if a public employee's speech was made as part of his or her job duties, discipline or dismissal does not violate the individual's First Amendment rights. In this case, a deputy district attorney for the Los Angeles County District Attorney's office believed there were inaccuracies in an affidavit used to obtain a critical search warrant. He informed his supervisors of his beliefs and followed up by preparing a disposition memorandum. This document explained the plaintiff's concerns and recommended dismissal of the case that the district attorney was pursuing. Despite these concerns, his supervisors proceeded with the prosecution. During a hearing regarding the case, the plaintiff was called as a witness by the defense and recounted his concerns. He alleged that, after these events, a series of retaliatory employment events occurred. These included reassignment from his calendar deputy position to a trial deputy position, transfer to another courthouse, and denial of promotion. The Supreme Court ruled against the plaintiff, stating that when public employees make statements as part of their official duties, it is not protected speech. Since the plaintiff was not acting as a citizen when he wrote the memo but as a public employee, he did not have First Amendment protections and could be disciplined.

Recently, the Kansas Board of Regents announced it planned to re-evaluate a social media policy that gives executives at the state's public colleges the authority to terminate the employment of faculty members and employees for improper social media statements; this re-evaluation is due to concerns from faculty and students that it infringes on the right to free speech. ${ }^{13}$ This policy was passed on December 18, 2013, in response to a University of Kansas journalism professor who was placed on leave after tweeting about members of the National Rifle Association. Of the two categories of online speech delineated in the policy, the first category is speech made "pursuant to" or "in furtherance of" official duties and can be completely regulated. Discipline up to and including loss of employment can be imposed for speech that is thought to be "contrary to the best interest" of the institution.

\section{Contract Law}

Students and faculty members at private institutions are less affected by First and Fourteenth Amendment rights infringement, so they are guided 
largely by contract law. Faculty members sign employment contracts as a precursor to their appointments. Students may be asked to sign contracts in the form of agreements to comport themselves in congruence with institutional policy when they are admitted, or they may enter into a contract when they enter a clinical setting within the institution. Students are generally required to sign a contract agreeing to follow the policies stated in a clinic manual or student handbook or catalog.

Contract law principles are utilized at both public and private institutions. Manuals and handbooks, produced in both types of educational settings, are useful in giving guidance to students and faculty on acceptable behavior and actions and form a basis for upholding disciplinary action when necessary. The majority of clinic manuals and student handbooks now include social media and patient confidentiality sections in them in order to make school policy clear and to make these provisions part of the "contract" with the student. Many students, faculty members, and administrators may not understand that, by agreeing to follow a handbook or manual, they are essentially signing a contract with which they agree to comply with regard to procedures and policies located in those documents. Faculty employees may also be required to sign agreements to adhere to the institutional Code of Conduct and to institutional computer use policies that govern privacy and security of personal identification information pertaining to patients. In this case, employees and students are on notice that violation of federal privacy laws are also violations of institutional policy and have serious consequences for continued status as an employee or a student.

An excellent example of a contract created by a catalog that affected student status was illustrated by University of Texas Health Science Center at Houston v. Babb, which occurred in the early $1980 \mathrm{~s} .{ }^{14}$ The case involved a student who entered the nursing program at this public university under the admission requirements of the program's 1978-79 catalog, which stated that a student would be placed on probation if his or her grade point average (GPA) fell below 2.0. The catalog stated that the grade incorporated into a student's transcript and thus used to calculate the GPA after a student repeated a course would be the grade from the repetition of the course. The catalog also indicated that rules governing academic progress and disciplinary actions would be those in place when the student entered the program and those rules would define requirements for completing the course of study into which the student had entered.
Subsequently, the 1979-81 catalog was updated to include the new policy that a student who received more than two Ds in the program would be required to withdraw. During the course of her progress through program, this student received notification that she was being dismissed from the program because the policy required this of any student with a total of three Ds, Fs, or WFs. She brought suit, contending that the later catalog with the provision stipulating that a student could receive no more than two Ds should not apply to her because she entered school when the previous catalog in place. In its ruling, the Texas Court of Appeals agreed with the student, stating that the catalog constituted a written contract between the school and the student.

This case is a good example of the impact of contract law. The 1978-79 catalog was interpreted as a contract between the students and the university, which is a common interpretation at colleges and universities. The administration clearly misunderstood that terms and conditions described in the catalog formed an enforceable contract with students, a misunderstanding that led to the litigation.

This case, while occurring at a public university, illustrates the importance of contract law in both public and private institutions, but there are inherent differences related to the relative balance of controlling law between the two types of institutions. Students and faculty members at private institutions are not protected to the same degree by the First and Fourteenth Amendments as their counterparts at public schools because they have voluntarily agreed to specific conditions and behaviors consistent with the philosophy and mission of the private institutions. Consequently, contracts, which are enforced as such because of the promise to students made by outlining expectations in manuals and catalogs, become implied contracts. Implied contracts are arguably of even greater importance to faculty and students at private schools. However, contract law with respect to compliance with policy is important at all institutions. Faculty members at private institutions are not government employees and thus will not be judged by the evaluations formulated by the Pickering, Connick, and Myers cases for freedom of speech issues. Faculty members at private institutions likewise do not have the same automatic right to due process protections that their public counterparts enjoy unless the institutions in which they work have developed policy to permit this.

Students at private institutions are similar to those at public schools in that contracts implied by 
policies that are published in manuals and catalogs and even syllabi govern what is acceptable behavior for students and how they can be disciplined and how faculty members must comport themselves during the course. Well-written, clear policies that are easily interpreted by students are necessary and should include policies and guidelines for use of social media, as in the one for the University of Kentucky. ${ }^{15}$ Students and faculty should be educated that these manuals and catalogs are contracts and should be treated in that manner. Failure to read and understand what is and is not expected behavior can lead to disciplinary action. Administrators should ensure that they understand their policies and manuals and be sure to follow proper due process should discipline become necessary. The legal office of the institution should be called upon to help in the development of clear policies that can be upheld should legal challenges ensue.

\section{Conclusion}

The world is becoming a much smaller place at a rapid pace because of communication vehicles such as the various social media mentioned in this article. The manner in which people communicate is changing at an even faster speed. Advances in technology have enabled people to post everything about their lives and everything about their families' lives on Facebook. Through Twitter, people tweet about everything they do in a day and everywhere they go. It seems as if everyone, especially the group of adolescents and young adults whom psychologists have dubbed the iGeneration, is saying "Look at me."16 There are definitely advantages to faster and more effective communication, including improvements in both patient care and student education. Medical and dental care, research, and education have all benefitted from improved communication and having the right information "just in time." However, similar to most advances in technology, there are often unforeseen problems that can arise whenever these advances are implemented.

Currently, as has frequently been the case when technology moves faster than the law, the justice system and consequently university administrators are struggling with the balance between student and faculty right to free speech and efficient and equitable operations of their schools. The ubiquitous use of social media often blurs the lines between student and faculty member or patient and provider. The need for well-delineated, unambiguous policies regarding social media has been established. Additionally, an understanding of the court cases upon which these new social media policies were formed, as well as of the cases that clearly illustrate the status of the law regarding free speech concepts, helps students,

Table 3. Guidelines for social media communication

\begin{tabular}{cc} 
Activity & Potential Benefits \\
\hline Faculty/student communi- & More accessibility
\end{tabular}

Faculty/student communi- More accessibility cations with patients

Faculty/student posting of personal information/ pictures on social media

Faculty/student use of digital venues for communicating with colleagues about patient care

Faculty/student communi- Mentoring cation on social media

Posting comments about patients on blogs, Facebook, MySpace, etc.
Networking; very little benefit

Ease of communication; access to more information; better patient care None
Potential Issues Confidentiality concerns, loss of direct patient contact, misinterpretation of digital interactions, students possibly "practicing" without a license by giving treatment advice without faculty present

Blurring of professional and personal lives; impact on respect for faculty, student, and professions in community and with colleagues

Confidentiality concerns, unsecured networks, accessibility of protected health information

Blur lines between personal and professional

Possible "venting" that disparages patients and colleagues
Recommended Safeguards

Establish guidelines for when digital communications are OK and secure; save for patients who also maintain face-to-face follow-up

Tight security settings

Ensure security of messaging and information sharing; follow institutional practice and policy for remote and mobile access of protected health information

If necessary, have academic-only sites and communicate strictly regarding classroom activities

Not recommended; consider the content and message about the posting sends about individual, university, and profession 
faculty, and administrators have a deeper understanding of the concepts involved. Finally, guidelines to inform policy development governing online activities, which include potential issues and recommended safeguards, as well as an example of a strong social media policy, can help all participants in the university community have positive experiences using this powerful technology (see Table 3 for sample guidelines based on those in a position paper from the American College of Physicians and Federation of State Medical Boards ${ }^{17}$ ).

Technology and electronic communication will continue to evolve and expand at an exponential pace. Those who utilize these new products and services will need to be constantly evaluating how they can get the most out of their use, while being cognizant of potential unforeseen problems. Similarly, the justice system and universities will be forced to continue to try and find the right balance between free speech of the participants and the rights of all stakeholders in the university and the community.

\section{REFERENCES}

1. McAndrew M, Johnston AE. The role of social media in dental education. J Dent Educ 2012;76(11):1474-81.

2. Chaplinsky v. New Hampshire, 315 U.S. 568 (1942).

3. Doe v. University of Michigan, 721 F. Supp. 852 (E.D. Mich. 1989).

4. UWM Post v. Board of Regents of the University of Wisconsin System, 774 F. Supp. 1163 (E.D. Wisc. 1991).
5. Wassom B, Pauwels AM. Social media and student speech in colleges and universities. At: http://wassom.com/socialmedia-and-student-speech-in-colleges-and-universities. html. Accessed: January 20, 2014.

6. Byrnes v. Johnson County Community College, 2011 WL 166715 (D. Kan., Jan. 19, 2011).

7. Yoder v. University of Louisville, $12-5354$ ( $6^{\text {th }}$ Cir., May $15,2013)$.

8. Board of Curators of the University of Missouri v. Charlotte Horowitz, 435 U.S. 78 (1978).

9. Wassom B, Pauwels AM. Social media and faculty discipline. At: http://wassom.com/social-media-and-facultydiscipline.html. Accessed: January 20, 2014.

10. Pickering v. Board of Education of Township High School District 205, Will County, 391 U.S. 563 (1968).

11. Connick v. Myers, 461 U.S. 138 (1983).

12. Garcetti et al v. Ceballos, 547 U.S. 410 (2006).

13. Jaschik S. Fireable tweets. Inside Higher Ed, December 19, 2013. At: www.insidehighered.com/news/2013/12/19/ kansas-regents-adopt-policy-when-social-media-use-canget-faculty-fired. Accessed: January 20, 2014.

14. University of Texas Health Science Center at Houston v. Babb, 646 S.W.2d 502 (Tex Ct. App. 1982).

15. University of Kentucky. Social media policies and guidelines: administrative regulation 10.4. Lexington: University of Kentucky, Information Technology/Public Relations and Marketing Departments, 2011.

16. Rosen L. Rewired: understanding the iGeneration and the way they learn. New York: Palgrave Macmillan, 2010.

17. Farnan JM, Sulmasy LS, Worster BK, et al. Online medical professionalism: patient and public relationships - policy statement from the American College of Physicians and the Federation of State Medical Boards. Table: online physician activities - benefits, pitfalls, and recommended safeguards. Ann Intern Med 2013;158(8):620-7. 